\title{
Editorial
}

\section{Demystification and Disruption}

The articles in European Comic Art 13.1 all allude to the capacity of comics for demystification and disruption. This may take the form of a mistrust of canons; a retelling of the lives of painters that subtly, or less subtly, debunks the mythology of the great artist; an assault on the sensibilities of those who cling to a male-defined idealisation of the female body; a refusal of the illusion of depth in favour of a more complex mapping of connections across surfaces; or the subversive appropriation of a genre previously based on colonial assumptions.

Laurence Grove's article is a (slightly expurgated) version of his address to the 2019 International Bande Dessinée Society conference in Manchester in which he proposed a retrospective of twenty years of IBDS conferences from 1999 to 2019, starting with reminiscences from participants about encounters with artists and with pioneers of comics theory, followed by a tabular summary of places, people and highlights, and then by a reflection on the evolution of comics studies as evinced by the papers presented over that period. He detects a shift in emphasis from a cultural studies approach, as a discipline in search of legitimacy focused on the treatment of social conflict or gender issues, towards the establishment of a body of theory on the signifying practices of the medium itself, and on the process of creation. He notes also that as comics have escaped the bounds of the page to plunge into a multimedia environment, so comics criticism has extended beyond the academy into online forums and blogs, resulting in a shattering but also a certain renewal of the canon. His conclusion reaffirms his enthusiasm for a medium that can still thumb its nose at corporate culture.

Matthew Screech investigates eight comics albums about Paul Gauguin and Vincent Van Gogh that have appeared since 1990, which simultaneously uphold and subvert mythologies around the figure of the great artist, in a postmodern climate in which myths, and the tenacious desire for myths, are subject to deconstruction. In the first, by Dick Matena, techniques of selective framing, masking and then 
revealing, immerse the reader in the narrative, but multiple narrators, some clearly unreliable, reintroduce a certain distance. In the second, by Li-An and Laurence Croix, a mainly unremarkable page layout and restrained drawing style tend to accredit Gauguin's far from dependable memoirs, until a sudden shift into garish colour dispels the effect of realism. The third, by Maximilien Le Roy, Christophe Gaultier and Marie Galopin, is based on the writings of Victor Segalen, the very writings that contributed to the mythologisation of Gauguin, which the comic both amplifies through its use of sensual, Gauguin-style images and intermittently exposes as an enterprise of fabrication. Two comics by Grandimir Smudja depart much more conspicuously from realism: in one, the reader's demand for period detail is met by the inclusion of careful reproduction of famous impressionist and post-impressionist paintings as backdrops, while the creation of Van Gogh's canvasses is attributed, absurdly, to a cat. In the other, Van Gogh and Gauguin engage in time travel: Screech maintains that the preposterousness of this premise is itself a form of mythologisation. The sixth of Screech's choices, by Bruno Le Floc'h, portrays convincing Breton landscapes, but realism in relation to Gauguin's life is undermined through a play of knowing intertextual references. The seventh, by Barbara Stok, recirculates the myths around both artists, but in somewhat sanitised form, minus brothels and suicide. The eighth, by Fabrizio Dori, concerning Gauguin, wholeheartedly embraces myth, enhancing it by the addition of a Polynesian spiritual dimension, likely to diminish credibility for sceptical readers. In his conclusion, Screech signals the manifold resources of the comics medium for both contributing to and foregrounding the process of mythologisation. He also notes that this venture into fine art subject matter by a low-status medium may have a legitimising function.

Mike Classon Frangos considers the work of Liv Strömquist, the Swedish cartoonist whose metro station installation, the 2018-2019 Night Garden featuring menstrual art, scandalised some. In her comics, he explains, Strömquist uses humour not only to disrupt conventional representations of female bodies but also to reflect explicitly on the fact that scientific 'knowledge' in this domain, far from being neutral, has been constructed mainly by men who have an interest in exercising power over those bodies. In his discussion, Frangos uses Eve Sedgwick's notion of 'reparative reading', which she distinguishes from 'paranoid reading'. While the latter seeks to track the power relations hidden beneath the surface of the text, the former proposes a more 
open approach that is oriented towards affect and action. Frangos finds a 'reparative' approach in Strömquist's work: alongside a critique of dominant discourses on sex and gender she is just as capable of offering a (possibly ironic) celebration of the gender binary as she is of imagining queer alternatives. He goes on to discuss Strömquist's work in menstrual activism, pointing out that comics have played a key role in this movement since the 1990s, most famously those of Julie Doucet, who repeatedly and exuberantly depicted menstrual bleeding. Strömquist evokes the possibility of male menstruation, which would, by definition, not be taboo but rather a subject of boasting and rivalry, and also envisages a matriarchal society, in which menstruation would be revered. Frangos shows how she uses metatextual strategies, including self-reflexive commentary, to unsettle habitual norms and definitions of gender and, in a reparative move, to look beyond their limits. He concludes his essay by considering why an image of a visibly menstruating woman in Strömquist's Stockholm metro exhibition provoked such strong reactions and proposes that it is the calm matter-of-factness of the woman's gaze at the viewer that creates discomfort, by its denaturalising of the taboo, part of a general project that aims to redraw the limits of representation of the female body.

Simone Castaldi opens his article by referring to Italo Calvino's 1983 Palomar, in which the hero notes how the inexhaustible surface of things' has come to dominate our perceptions at the expense of the search for hidden depth, a tendency greeted by theorists of postmodernity as a part of a welcome renunciation of hierarchies. In the Italian comics world, a symptom of this cultural upheaval was the displacement of a canon of comics auteurs, including Hugo Pratt and Guido Crepax, by new groups of artists who were responding to the political crises of the 1970s. Stefano Tamburini was the founder of two comics magazines, Cannibale and Frigidaire, which attracted a politically dissident readership. His own work used collage to juxtapose avant-garde works with mass-cultural products through techniques of collage. Castaldi notes that as an art of reproduction that dispenses with the aura of the original, comics is well placed to engage in the desanctifying practices initiated by Dada artists. He points to the availability of Xerox machines as a key factor in the development of a cut-andpaste punk aesthetic in the 1970s, embodied by Tamburini's own early comics character, the android RanXerox, whose vision of the world as a series of photocopies levelled out social and cultural layers. By the late 1970 s, when left-wing movements were experiencing severe repression 
in Italy, Tamburini acknowledged political disillusion by eliminating Modernist elements. His 1980s series Snake Agent, for example, appropriated panels from a US spy series, and de-dramatised the Futurist obsession with speed: the action was violently accelerated simply by an exacerbation of the mechanism of ellipsis through which temporal depth is translated into spatial flatness. In these later works, the interplay between the quoted text and the artefact, claims Castaldi, results in a pastiche that, unlike Lichtenstein's pop art comic strip blow-ups, does not reinstate the high / low art divide but rather renders it irrelevant. Moreover, the perspectival rationality on which modernity is founded gives way to a postmodern art of the surface that establishes interconnections, with social and political resonance, across a horizontal plane.

Dani Filc begins his discussion of comics heroes Tintin and Corto Maltese by framing the adventure genre, and the nineteenth-century plot structures on which it draws, within the Enlightenment conception of modernity as progress and knowledge, a philosophy that justified the racial hierarchy implicit in the colonial enterprise. But while the Tintin series began at the height of Franco-Belgian colonial supremacy, Corto Maltese began in the context of the radical and anti-colonial ferment of the 1960s. Filc identifies two tendencies among Tintin scholars: those who argue that the colonialist world view of the early albums evolves into a more universalist, humanitarian outlook in the later albums, and those who emphasise the persistence of a reactionary political stance throughout the œuvre, including an anti-Semitic strain. Filc finds the latter approach plausible, even if the albums may seem to display contradictory attitudes towards colonialism: Tintin is capable of defending good natives against evil Westerners, but only as a white saviour protecting the primitive colonial subjects, and the origins of Haddock's wealth in colonial plunder and slavery are erased. Corto Maltese, in contrast, explicitly supports anti-colonial movements and revolutionary uprisings. In a masculinist genre, he includes female characters who, far from being ridiculed like Hergé's Castafiore, are depicted as actors in political struggles. He does not, though, Filc points out, always avoid the stereotype of woman as manipulative. And while Pratt's portrayal of colonialism in Africa may be described as nuanced in its recognition that the colonial hierarchy intersects with traditions of inequality predating the arrival of Europeans, it can fall into a simplistic representation of the colonial other as mysterious and barbaric. It is in the stories set in Latin America that Filc finds the greatest divergence between Tintin and Corto. Where the former flees back to Europe at the end of 
his final adventure, Tintin et les Picaros, finding the revolutionaries to be as corrupt as their opponents, in contrast to the morally upright Europeans, the latter commits himself to the struggles for justice of landless peasants, his cynicism challenged by their courage.

We hope that for the next twenty years IBDS conferences will continue to promote comics as a thorn in the side of the powerful and complacent, just as our contributors have shown it to be across several countries and many decades. And here at European Comic Art, we will do our best to help the process along. 